\title{
Square-Wave Voltammetric Sensing of Lawsone (2- Hydroxy-1,4-Naphthoquinone) Based on the Enhancement Effect of Cationic Surfactant on Anodically Pretreated Boron-Doped Diamond Electrode
}

\author{
Pınar Talay Pınar, ${ }^{1 *}$ Yavuz Yardım ${ }^{1}$ and Zühre Şentürk ${ }^{2}$ \\ ${ }^{1}$ Yuzuncu Yil University, Faculty of Pharmacy, Department of Analytical Chemistry, 65080 Van, Turkey \\ ${ }^{2}$ Yuzuncu Yil University, Faculty of Science, Department of Analytical Chemistry, 65080 Van, Turkey \\ *Corresponding author: E-mail: ptalay@gmail.com \\ Tel: 5057649740
}

Received: $12-08-2020$

\begin{abstract}
In this reported work, an anodically pretreated boron-doped diamond (BDD) electrode was used for the inexpensive, simple and quick detection of a natural dye, lawsone. Lawsone had a well-defined, irreversible and diffusion-controlled oxidation peak at approximately $+0.19 \mathrm{~V}$ in phosphate buffer solution (PBS, $0.1 \mathrm{M}, \mathrm{pH} 2.5$ ) using cyclic voltammetry (CV). The oxidation peak heights of lawsone were significantly increased in PBS using the cationic surfactant cetyltrimethylammonium bromide (CTAB). Under optimized experimental conditions, the calibration curve was linear over a concentration range of $0.1-5.0 \mu \mathrm{M}$ with detection limit of $0.029 \mu \mathrm{M}$ in $0.1 \mathrm{M}$ PBS (pH 2.5) containing $0.1 \mathrm{mM}$ CTAB by using square-wave voltammetry (SWV). To evaluate the practical applicability of the BDD electrode, it was used for the quantification of lawsone in commercial henna, a natural dye made from the leaves of the henna plant.
\end{abstract}

Keywords: Lawsone; boron-doped diamond electrode; square-wave voltammetry; cetyltrimethylammonium bromide; henna samples

\section{Introduction}

Lawsone (2-hydroxy-1,4-naphthoquinone) (Figure 1.), known as hennotannic acid, is a red-orange dye found in the leaves of the henna plant (Lawsonia inermis) and water hyacinth flower. ${ }^{1-3}$ Henna extract or its purified compounds exhibit a variety of biological activities such as antimicrobial, cytotoxic, anti-inflammatory, antioxidant, anticancer and analgesic activities. Henna leaves have been used as a cosmetic colorant for centuries and contain a high proportion of lawsone (1.0-1.4\%). ${ }^{4-7}$ Lawsone is also used as a corrosion inhibitor for metals such as aluminum (Al), iron $(\mathrm{Fe})$, zinc $(\mathrm{Zn})$ and nickel $(\mathrm{Ni})$ in both acidic and alkaline solutions. A survey of the literature revealed that chromatographic methods such as high-performance liquid chromatography with ultraviolet detection (HPLC-UV) and liquid chromatography-tandem mass spectrometry (LC/MS-MS) were used for determination of lawsone content in plant extracts prepared from leaves, shoots and fruits. ${ }^{8-12}$ Voltammetric techniques were also applied for lawsone analyses. ${ }^{13,14}$<smiles>O=C1C=C(O)C(=O)c2ccccc21</smiles>

Figure 1. Structure of lawsone

Boron-doped diamond (BDD) electrode, a specific form of carbon, is widely used in both aqueous and non-aqueous media. It has important properties such as wide electrochemical potential window, low and stable background current, relative insensitivity to dissolved oxygen, low adsorption of pollutants, mechanical stability and high repeatability. ${ }^{15-19}$ Therefore, this electrode, used in many different application areas, is very important in terms of electroanalytical chemistry. 
However, it should be noted that for many electroactive substances the BDD electrode is highly dependent on surface termination, which can be replaced by appropriate electrochemical pretreatment (anodic or cathodic) ${ }^{20}$ or mechanical treatment. ${ }^{21}$ To our knowledge, no study related to the determination of lawsone using a BDD electrode has appeared in the literature.

In this paper, the electrochemical oxidation and detection of lawsone using BDD electrode is explained for the first time. Lawsone is an electroactive compound and it is possible to measure its amount in real samples through oxidation. Determination of lawsone in commercial henna samples was carried out using square wave voltammetry.

\section{Experimental}

\section{1. Chemicals}

Lawsone (2-Hydroxy-1,4-naphthoquinone), acetic acid, hydrochloric acid, phosphoric acid, boric acid, monobasic sodium phosphate and sodium hydroxide were obtained from Sigma-Aldrich, Turkey. Henna samples were obtained from a commercial local herbalist. All chemicals used were at least analytical grade and their solutions were prepared with deionized water further purified with a Milli-Q unit (Millipore). Because of lawsone's low solubility in aqueous solution, stock standard solutions $(0.01 \mathrm{M})$ were prepared in methanol. It was stored at $+4{ }^{\circ} \mathrm{C}$ when not in use and protected from daylight during use in the laboratory. Phosphate (0.1 M, pH 2.5 and 7.4), Britton-Robinson (BR, 0.1 M, pH 2-8), and acetate (0.1 M, pH 4.7) buffers were used as supporting electrolyte solutions.

\section{2. Apparatus and Analytical Procedure}

All electrochemical experiments were carried out at room temperature using an Autolab PGSTAT128N (Metrohm Autolab B.V., The Netherlands) which was managed by the software GPES 4.9. The counter electrode was platinum wire, the reference electrode was $\mathrm{Ag} / \mathrm{AgCl}$ electrode and the working electrode was a BDD electrode (3 mm diameter, geometric surface area of $0.07 \mathrm{~cm}^{2}$ and declared boron doping level of 1000 ppm). Before experiments, the BDD electrode was electrochemically pretreated in an independent electrochemical cell. At the start of each experiment day, anodic pretreatment was completed by applying $+1.8 \mathrm{~V}$ (unless otherwise stated) for $180 \mathrm{sec}-$ onds in $0.5 \mathrm{M} \mathrm{H}_{2} \mathrm{SO}_{4}$ solution. ${ }^{16,23}$ An activation program was used with 30 seconds duration in the same experimental conditions between individual measurements. Later, the BDD electrode surface was used directly for voltammetric measurements with repeatable signals.

The analytical performance and practical applicability were assessed using SWV, with the optimized operating parameters (frequency $(f) 75 \mathrm{~Hz}$; step potential $\left(\Delta E_{s}\right), 14$ $\mathrm{mV}$; pulse amplitude $\left.\left(\Delta E_{\mathrm{sw}}\right), 14 \mathrm{mV}\right)$. All voltammetric measurements were carried out in triplicate at room temperature.

SW voltammograms were recorded after each addition of the study compound. Validation parameters like precision, accuracy, linearity, LOD (detection limit) and LOQ (quantification limit) were calculated. LOD and LOQ values were found using the following equations.

$$
\mathrm{LOD}=3 \mathrm{~s} / \mathrm{m} ; \mathrm{LOQ}=10 \mathrm{~s} / \mathrm{m} \text {, }
$$

where, $s$ is the standard deviation of the peak current at minimum concentration in the relevant linear interval (preliminary study) and $\mathrm{m}$ is the slope of the relevant calibration curve.

About $0.1 \mathrm{~g}$ of commercial henna sample was dissolved in $5 \mathrm{~mL}$ of ethanol and diluted to $20 \mathrm{~mL}$ with $\mathrm{pH}$ 2.5 phosphate buffer solution, stirred at room temperature for 90 minutes and filtered. The obtained filtrate had SW voltametric studies completed with cationic surfactant, CTAB, using $0.1 \mathrm{M}$ PBS in $\mathrm{pH} 2.5$ solution. An aliquot volume $(20 \mu \mathrm{L})$ of these solutions was transferred to the voltammetric cell containing the same solution, and analyzed on the day of preparation according to the procedure developed for the pure electrolyte using the calibration curve for the related regression equation.

\section{Results and Discussion}

\section{1. Investigation of the Electrochemical Behavior at the Boron Doped Diamond Electrode}

The electrochemical behavior of lawsone was examined by the CV method on the anodic pre-treated (APT) BDD electrode (see below for pre-treatment studies) surface. With $0.2 \mathrm{mM}$ lawsone, $0.1 \mathrm{M} \mathrm{PBS}, \mathrm{pH} 2.5$ in the interval -0.5 to $+0.6 \mathrm{~V}$ at $100 \mathrm{mV} \mathrm{s}^{-1}$ scanning rate, CV was studied in three cycles. In the oxidation step, a well-defined anodic peak was obtained at nearly $+0.19 \mathrm{~V}$ for lawsone on the first scan. In the reverse scan (return), a reduction peak was obtained at nearly $-0.20 \mathrm{~V}$ (Figure $2 \mathrm{~A}$ ).

The effects of the scan rate for $0.2 \mathrm{mM}$ lawsone on the peak current was assessed with cyclic voltammetry at different scan rates from 10 to $600 \mathrm{mV} \mathrm{s}^{-1}$ at $\mathrm{pH} 2.5$ in 0.1 $\mathrm{M}$ PBS. As can be seen in Figure 2B, the oxidation peak shifted toward more positive potential as the scan rate increased. The results show that the lawsone oxidation peak current (Ia) increased linearly with the square root of increasing scan rate $\left(v^{1 / 2}\right)$ and can be expressed as follows:

$$
\begin{aligned}
& \text { Ia }(\mathrm{nA})=258.98 v^{1 / 2}\left(\mathrm{mV} \mathrm{s}^{-1}\right)^{1 / 2}-306.96, \\
& (r=0.999, n=7)
\end{aligned}
$$

In addition, the linearities of plots of $\log i_{\mathrm{p}}$ versus $\log$ $v$ are expressed as follows: 

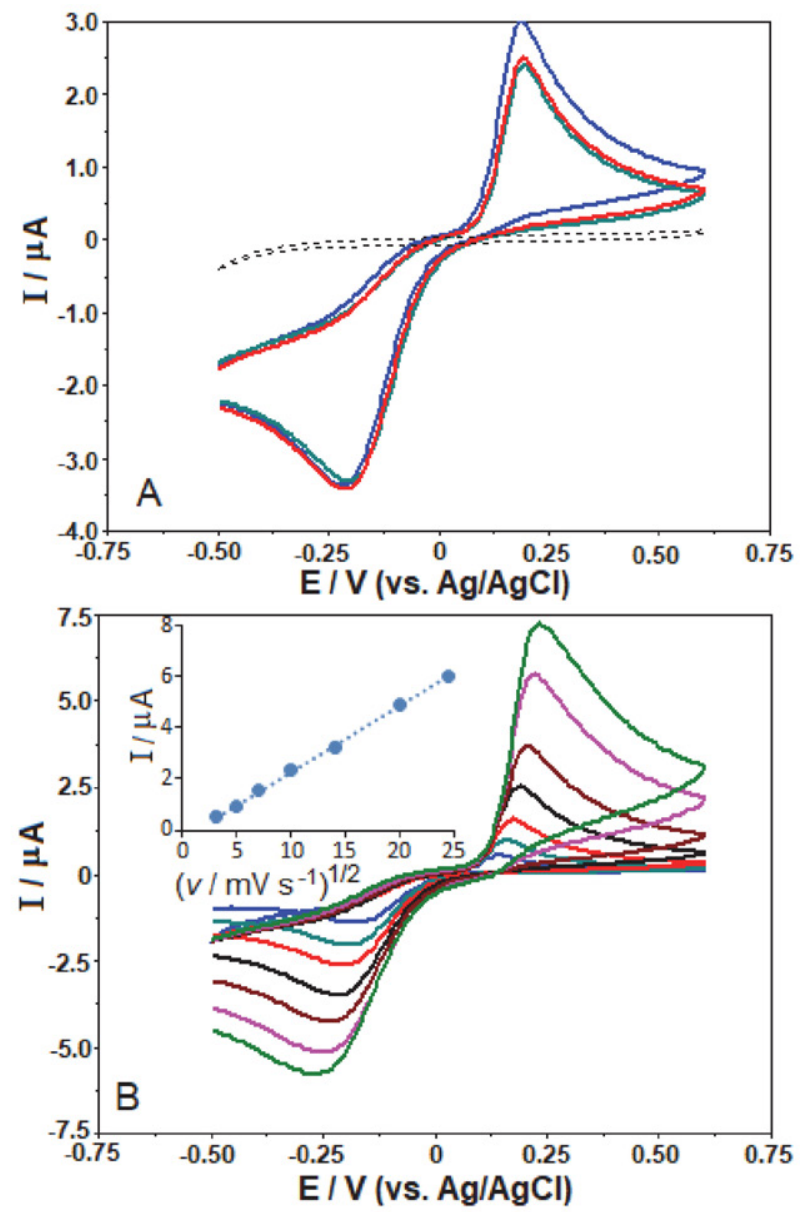

Figure 2. The repetitive cyclic voltammograms at scan rate of 100 $\mathrm{mV} \mathrm{s}^{-1}(\mathrm{~A})$, and the cyclic voltammograms at different scan rates $\left(10,25,50,100,200,400\right.$ and $\left.600 \mathrm{mV} \mathrm{s}^{-1}\right)(\mathrm{B})$ of $0.2 \mathrm{mM}$ lawsone solutions in $0.1 \mathrm{M}$ phosphate buffer ( $\mathrm{pH}$ 2.5) solution. A; Dashed lines represent background current. B; Inset depicts the plot of peak current $(I a)$ vs. square root of the scan rate $\left(v^{1 / 2}\right)$.

$$
\begin{aligned}
& \log I \mathrm{a}(\mathrm{nA})=0.588 \log v\left(\mathrm{mV} \mathrm{s}^{-1}\right)+2.169 \\
& (r=0.999, n=7)
\end{aligned}
$$

According to the findings above, the theoretical value of the slope is close to 0.5 , showing that lawsone electrooxidation on the APT-BDD electrode is basically diffusion controlled. It is known that the electrochemical response of electroactive molecules on BDD electrodes depends on the type of pre-treatment. When the BDD electrode is pre-treated anodically, its surface changes to predominantly oxygen-terminated; in the case of cathodic pre-treatment, the ratio of surface BDD electrodes predominantly changes to hydrogen-terminated. ${ }^{22}$ The electrode was treated both anodically $\left(+1.8 \mathrm{~V}\right.$ for $180 \mathrm{~s}$ in $\left.0.5 \mathrm{M} \mathrm{H}_{2} \mathrm{SO}_{4}\right)$ and cathodically $\left(-1.8 \mathrm{~V}\right.$ for $180 \mathrm{~s}$ in $0.5 \mathrm{M} \mathrm{H}_{2} \mathrm{SO}_{4}$ ) in this work. Figure 3 shows the voltammetric response obtained for the determination of $0.1 \mathrm{mM}$ lawsone in a $0.1 \mathrm{M}$ PBS ( $\mathrm{pH}$ 2.5) on an untreated or electrochemically (anodic and cathodic) pre-treated BDD electrode. As can be inferred from this figure, anodic pre-treatment of the BDD elec- trode leads to a higher oxidation peak current value than untreated or cathodic pre-treatment. Therefore, all the following experiments were carried out using an anodic pre-treated $\mathrm{BDD}$ electrode at $+1.8 \mathrm{~V}$ for 180 seconds. This electrochemical pretreatment procedure was repeated daily before starting the voltammetric measurements. It is worth mentioning that this anodic pretreatment (at $+1.8 \mathrm{~V}$ for $30 \mathrm{~s}$ ) procedure was carried out before each measurement in order to obtain reproducible and reliable results.

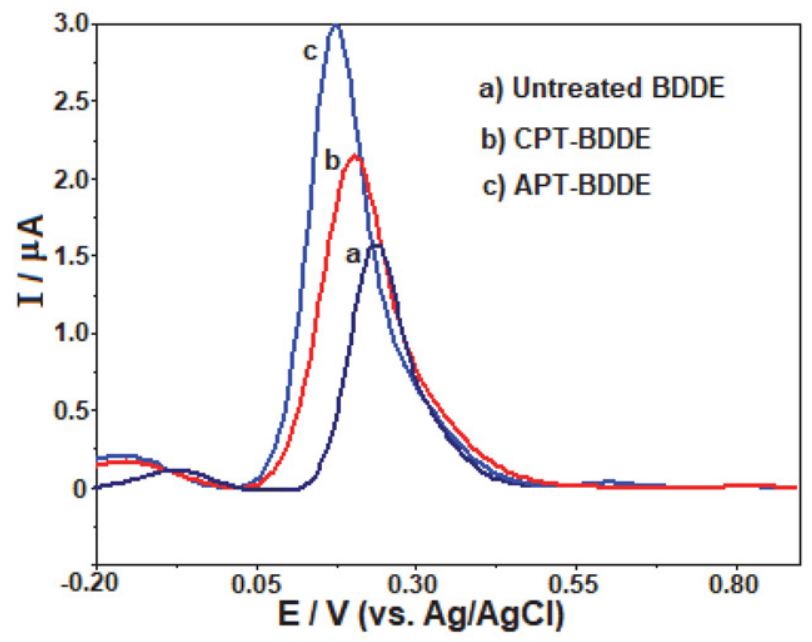

Figure 3. SW voltammograms of $0.1 \mathrm{mM}$ lawsone solutions obtained at untreated (a) and cathodically (b) or anodically (c) or pre-treated BDD electrode in $0.1 \mathrm{M}$ phosphate buffer $(\mathrm{pH} 2.5)$ solution. SWV parameters: frequency, $50 \mathrm{~Hz}$; step potential, $8 \mathrm{mV}$; pulse amplitude, $30 \mathrm{mV}$.

Further work was dedicated to analyzing the dependence of the voltammetric performance for the compound on the solution $\mathrm{pH}$ using APT-BDD electrode. In Figure $4 \mathrm{~A}$, this parameter was established in a series of BR buffers with $\mathrm{pH} 2.0-8.0$ by carrying out voltammetric measurements on $0.1 \mathrm{mM}$ lawsone solutions. For the peak potential $(E \mathrm{p})$ of lawsone, the $\mathrm{pH}$ value from 2.0 to 4.0 has little influence on the peak potential $(E \mathrm{p}(\mathrm{mV})=-20.0 \mathrm{pH}$ $+219.2, r=0.995)$, whereas no important shift of $E \mathrm{p}$ was observed between $\mathrm{pH} 4.0$ and 8.0. SW voltammograms of the different supporting electrolytes are shown in Figure 4B. Using $\mathrm{pH} 2.5$ and 7.4 of $0.1 \mathrm{M}$ phosphate buffer solutions, $\mathrm{pH} 4.7$ of acetate buffer solution had $E \mathrm{p}$ of $0.18,0.14$ and $0.09 \mathrm{~V}$, respectively. As can be seen from Figure 4, 0.1 $\mathrm{M}$ phosphate buffer $\mathrm{pH} 2.5$ was chosen as the most suitable medium because the maximum peak current of lawsone obtained with this solution.

To increase the sensitivity of the electrochemical process, the effect of cationic surfactant (positive charge) on the lawsone oxidation signal was assessed. Lawsone concentration was fixed to $0.1 \mathrm{mM}$ within $0.1 \mathrm{M}$ PBS (pH 2.5 ) and the concentration of $0.1 \mathrm{mM} \mathrm{CTAB}$ was investigated in the electrochemical cell. As can be seen on Figure 5 , the addition of CTAB to the electrochemical cell caused 

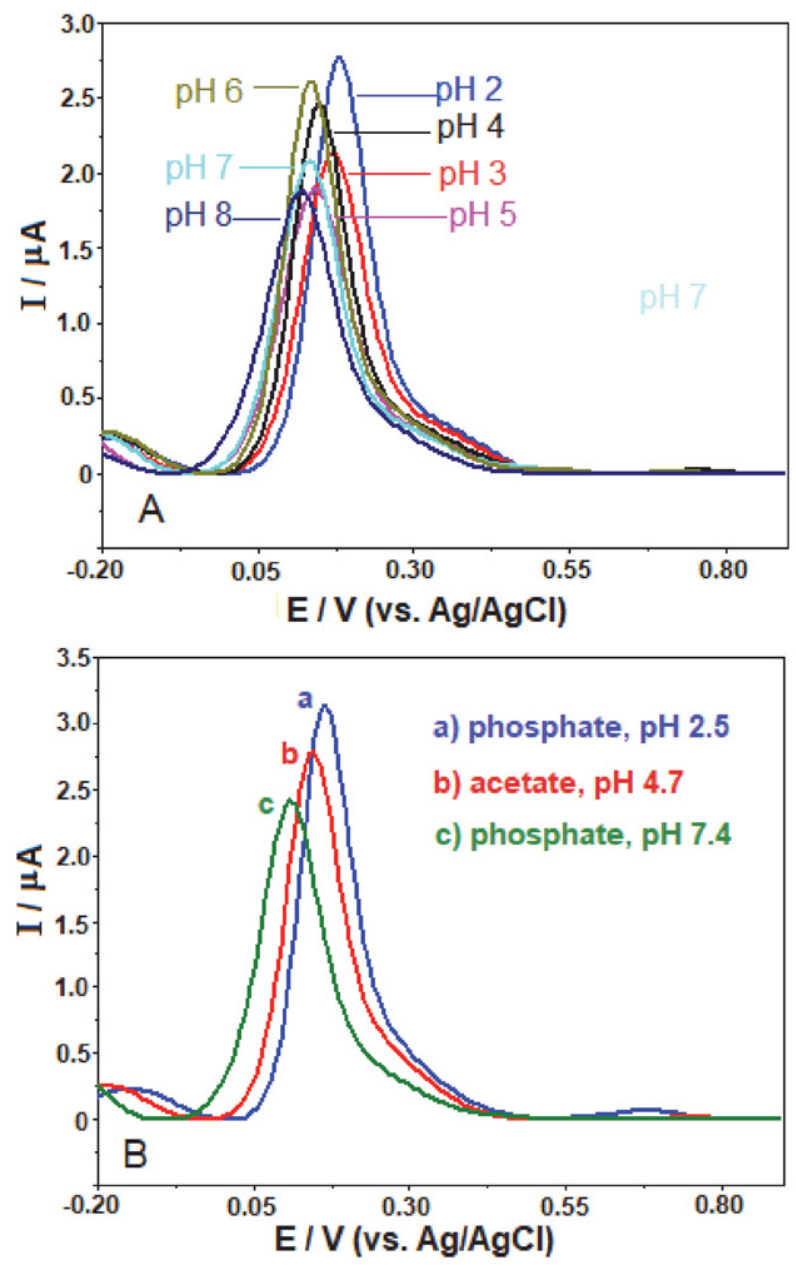

Figure 4. SW voltammograms of $0.1 \mathrm{mM}$ lawsone solutions in Britton-Robinson buffer $\mathrm{pH}$ 2.0-8.0 (A), and in various supporting electrolytes (B). Other operating conditions as indicated in Figure 3.

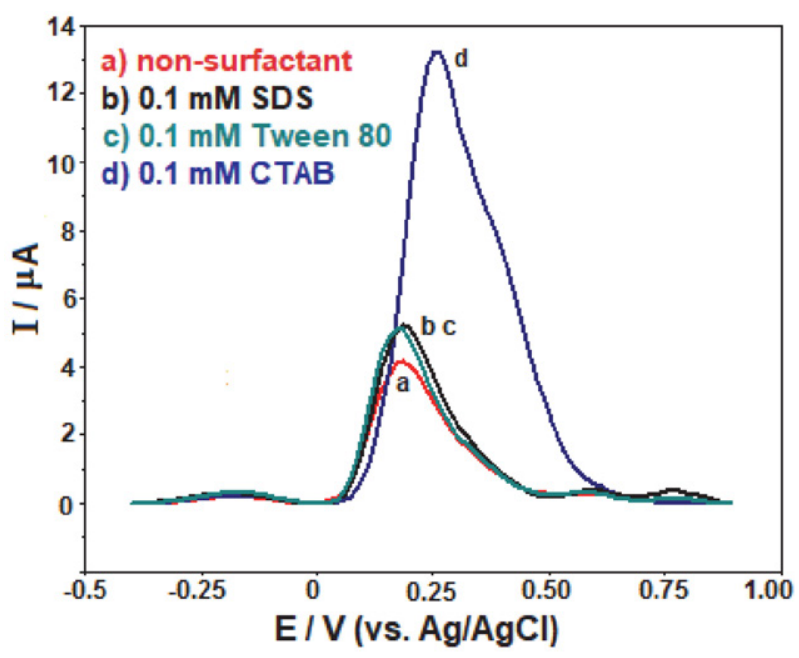

Figure 5. The $\mathrm{SW}$ voltammograms of $0.1 \mathrm{mM}$ lawsone solutions in phosphate buffer ( $\mathrm{pH} 2.5$ ) at the different surfactants' media on APT-BDD electrode. SWV parameters: frequency, $50 \mathrm{~Hz}$; step potential, $8 \mathrm{mV}$; pulse amplitude, $30 \mathrm{mV}$. the lawsone peak potential to shift to more positive potential. When the peak currents are compared in the presence and absence of CTAB, the electrochemical cell containing CTAB was observed to have peak current increased by 4 times. Later, in order to choose the most appropriate surfactant for analytic purposes, the electrochemical reactions with the anionic surfactant of sodium dodecylsulfate (SDS) and non-ionic surfactant of Tween 80 on lawsone were researched. Figure 5 gives the SW voltammograms for different surfactants with $0.1 \mathrm{mM}$ concentration. As can be seen on the figure, the cationic surfactant increased the peak current intensity by a significant degree compared to other surfactants, and at the same time caused a shift in peak potential.

The peak current obtained from SW voltammetry is linked to a variety of method parameters like frequency $(f)$, step potential $\left(\Delta E_{s}\right)$ and pulse amplitude $\left(\Delta E_{\text {sw }}\right)$. Optimizing the method parameters is important in terms of sensitivity. When the frequency changed between 15 and $125 \mathrm{~Hz}\left(\Delta E_{\mathrm{s}}=8 \mathrm{mV}, \Delta E_{\mathrm{sw}}=30 \mathrm{mV}\right.$, fixed $)$, the peak current increased linearly; however, the background current and noise increase at frequency values higher than $75 \mathrm{~Hz}$. When the step potential is changed from 4 to $16 \mathrm{mV}$ ( $f=$ $75 \mathrm{~Hz}, \Delta E_{\mathrm{sw}}=30 \mathrm{mV}$ ), the recorded signal increased up to $14 \mathrm{mV}$ and then slowly increased from 14 to $16 \mathrm{mV}$. Examining the form of the peak and current, the most appropriate step potential was evaluated as $14 \mathrm{mV}$. The effect of amplitude was investigated from 10 to $70 \mathrm{mV}\left(\Delta E_{\mathrm{s}}=14\right.$ $\mathrm{mV}, f=75 \mathrm{~Hz}$ ). The peak current of the molecule rapidly increased up to $70 \mathrm{mV}$. However, when assessed in terms of peak morphology, the sharper form of the peak and peak current, the most appropriate value was determined to be $60 \mathrm{mV}$. In conclusion, the generally optimized parameters for all experiments below can be summarized as $f=75 \mathrm{~Hz}$, $\Delta E_{\mathrm{s}}$ of $14 \mathrm{mV}$ and $\Delta E_{\mathrm{sw}}=60 \mathrm{mV}$.

\section{2. Analytical Applications}

Using the APT-BDD electrode, the most appropriate chemical conditions and instrumental parameters were created to record the analytic curve for the lawsone molecule in $0.1 \mathrm{M}$ PBS (pH 2.5) containing $0.1 \mathrm{mM} \mathrm{CTAB}$. Figure 6 shows the SWV curves obtained by successive addition of lawsone in the concentration interval from 0.1 to $5.0 \mu \mathrm{M}$. At $+0.19 \mathrm{~V}$ potential peak current, the lawsone concentration (Figure 6, inset) proportionally increased to give a very linear calibration graph: $i_{\mathrm{p}}(\mu \mathrm{A})=0.278 \mathrm{C}(\mu \mathrm{M})$ $+0.065(\mathrm{r}=0.999, \mathrm{n}=10)$. Here, $i_{\mathrm{p}}$ is peak current, $\mathrm{C}$ is lawsone concentration, $\mathrm{r}$ is the correlation coefficient and $\mathrm{n}$ is the number of experiments.

The LOD and LOQ values, calculated by using data for the calibration curve, were found to be $0.029 \mu \mathrm{M}$ and $0.097 \mu \mathrm{M}$, respectively. The comparison between lawsone estimation with the analytic parameters in the proposed method with some voltammetric methods previously reported in the lite rature is given in Table 1. 


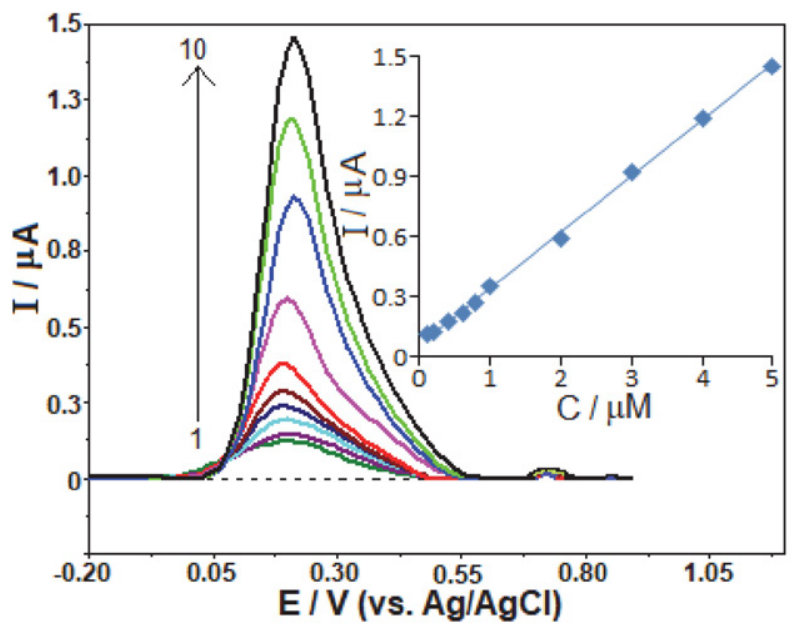

Figure 6. SW voltammograms for lawsone levels of (1) 0.1, (2) 0.2 , (3) 0.4, (4) 0.6, , (5) 0.8 , (6) 1.0 , (7) 2.0 , (8) 3.0 , (9) 4.0 and (10) $5.0 \mu \mathrm{M}$ in $0.1 \mathrm{M}$ phosphate buffer $(\mathrm{pH} 2.5)$ solution with $0.1 \mathrm{mM} \mathrm{CTAB}$. Inset depicts a corresponding calibration plot for the quantitation of lawsone on APT-BDD electrode. SWV parameters: frequency, 75 $\mathrm{Hz}$; step potential, $14 \mathrm{mV}$; pulse amplitude, $60 \mathrm{mV}$.

Table 1. Comparison of the efficiency of the anodically pretreated boron-doped diamond electrode (APT-BDDE), hanging mercury drop electrode (HMDE) and glassy carbon electrode (GCE), APT-BDDE, used for lawsone determination.

\begin{tabular}{lcc}
\hline Electrode & Detection Limit $(\mathbf{M})$ & Reference \\
\hline HMDE & $1.1 \times 10^{-7}$ & {$[13]$} \\
GCE & $6.0 \times 10^{-9}$ & {$[14]$} \\
APT-BDD & $2.9 \times 10^{-8}$ & This work \\
\hline
\end{tabular}

The intraday and interday repeatability at the BDD electrode was evaluated under optimum experimental conditions. The intraday repeatability of peak current magnitude was determined with successive measurements of $0.1 \mu \mathrm{M}$ lawsone solution. The results of ten repeated measurements provide a relative standard deviation (RSD) of $5.43 \%$ showing repeatability of results. Additionally, interday repeatability was done by measuring the magnitude of the peak current response for the same lawsone concentration at the BDD electrode on three consecutive days and the RSD was $6.87 \%$.

The practical usability of the proposed electroanalytical methodology was tested for a commercial henna sample by using the interlay corresponding regression equation in the calibration graph obtained for standard lawsone solutions. Sample preparation procedures are described in the relevant section in detail. The mean value of lawsone was found to be $0.59 \mu \mathrm{M}$ in the measurement cell. Taking into account the successive dilutions of the sample, $1.03 \%$ of lawsone was determined in the henna sample. The recovery experiments were completed with standard lawsone solutions $(0.1,0.6$ and $1.0 \mu \mathrm{M})$ added to $10 \mathrm{~mL}$ sample solution within the voltammetric cell and voltammetric reactions were evaluated (Figure 7). Recov- ery of lawsone was calculated in comparison with pure lawsone at the obtained concentration of the supplemented mixtures. The recovery varied from $91.8 \%$ to $103.7 \%$ and this shows no interaction effects of these matrices (Table 2). Lawsone can be quantitatively recovered with the proposed method, so there is a guarantee for the accuracy of lawsone voltammetric detection in commercial henna samples.

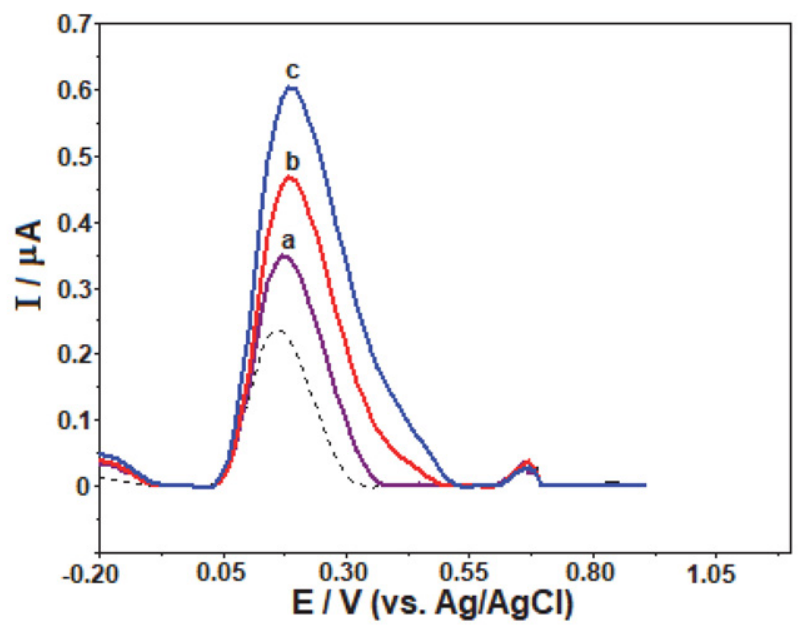

Figure 7. SW voltammograms of the diluted henna sample (dashed line) and after standard additions of 0.1 (a), 0.6 (b) and 1.0 (c) $\mu \mathrm{M}$ lawsone in $0.1 \mathrm{M}$ phosphate buffer $(\mathrm{pH} 2.5)$ solution with $0.1 \mathrm{mM}$ $\mathrm{CTAB}$ on BDD electrode. Other operating conditions as indicated in Figure 6.

Table 2 Results of the recovery analysis of lawsone (the average of three independent analysis of each spiked sample) in the sample of the commercial henna samples.

\begin{tabular}{lcc}
\hline $\begin{array}{l}\text { Lawsone added } \\
(\mu \mathrm{M})\end{array}$ & $\begin{array}{c}\text { Level } \\
\text { determined }(\boldsymbol{\mu M})\end{array}$ & $\begin{array}{c}\text { Recovery } \\
(\%) \pm \text { RSD }(\%)\end{array}$ \\
\hline 0 & 0.59 & - \\
0.1 & 0.63 & $91.8 \pm 5.05$ \\
0.6 & 1.26 & $105.9 \pm 4.43$ \\
1.0 & 1.65 & $103.7 \pm 3.31$ \\
\hline
\end{tabular}

\section{Conclusions}

This article represents the first successful attempt to investigate the electrochemical behavior of lawsone using APT-BDDE (without any modification of the electrode surface) coupled with the SW voltammetric method. Contributions to the sensitivity of the developed method were provided by a cationic surfactant (CTAB). The results indicated that one irreversible and diffusion-controlled anodic peak of lawsone was observed using $\mathrm{CV}$ at potential of about $+0.19 \mathrm{~V}$ in the presence of $0.1 \mathrm{M}$ in pH $2.5 \mathrm{PBS}$ as supporting electrolyte. 


\section{Acknowledgements}

The authors gratefully acknowledge financial support from the Van Yuzuncu Yil University Scientific Research Foundation (Project number: FBA-2017-5537).

\section{References}

1. A. K. Jordão, M. D. Vargas, A. C. Pinto, F. d. C. da Silva and V. F. Ferreira, RSC Adv. 2015, 5, 67909-67943.

DOI:10.1039/C5RA12785H

2. M. Monroy-Cárdenas, D. Méndez, A. Trostchansky, M. Martínez-Cifuentes, R. Araya-Maturana, and E. Fuentes, Front. Chem. 2020, 8, 533. DOI:10.3389/fchem. 2020.00533

3. K. V. Krishnamurthy, R. Siva, and T. K. Senthi, In Proceedings of National Seminar on the Conservation of the Eastern Ghats, Environment Protection Training and Research Institute, Hyderabad, 24-26 March 2002, pp. 151-153.

4. N. M. Rahmoun, Z. Boucherit-Otmani, K. Boucherit, M. Benabdallah, D. Villemin, and N. Choukchou-Braham, Méd. et Mal. Infec. 2012, 42, 270-275.

DOI:10.1016/j.medmal.2012.05.002

5. M. Barani, M. Mirzaei, M. Torkzadeh-Mahani, and M. H. Nematollahi, Daru 2018, 26, 11-17.

DOI:10.1007/s40199-018-0207-3

6. I. Al Nasr, J. Jentzsch, I. Winter, R. Schobert, K. Ersfeld, and W. S. Koko, Archiv. Pharm. 2019, 352, 1900128.

DOI:10.1002/ardp.201900128

7. S. B. Zaware, R. G. Gonnade, D. Srinivas, A. Khan, S. Y. Rane, New J. Chem. 2011, 8, 1615-1623. DOI:10.1039/c1nj20176j

8. F. Z. Alem, S. A. Gita, L. Cougnaud, C. Affnar, I. Nounah, B. Youssef, and B. Rhourri-Frih, Indus. Crops and Pro. 2020, 158, 112960-112960. DOI:10.1016/j.indcrop.2020.112960

9. H. Arkaban, M. Mirzaei, M. Behzadi, Preprints 2020, 2020090668 DOI: 10.20944 /preprints202009.0668.v1).
10. Y. Oda, S. Nakashima, E. Kondo, S. Nakamura, M. Yano, C. Kubota, and H. Matsuda, J. Nat. Med. 2018, 72, 890-896. DOI:10.1007/s11418-018-1221-y

11. P. Babula, R. Mikelova, D. Potesil, V. Adam, R. Kizek, L. Havel, and Z. Sladky, Biomed. Papers 2005, 149, 25-28.

12. N. S. El-Shaer, J. M. Badr, M. A. Aboul-Ela, and Y. M. Gohar, J. Sep. Sci. 2017, 30, 3311-3315. DOI:10.1002/jssc.200700223

13. P. Babula, J. Vanco, L. Krejcova, D. Hynek, J. Sochor, V. Adam, and R. Kizek, Int. J. Electrochem. Sci. 2012, 7, 7349-7366.

14. B. K. Chethana, S. Basavanna, Y. A. Naik, J. Anal. Chem. 2014, 69, 887-891. DOI:10.1134/S1061934814090044

15. S. Baluchova, A. Danhel, H. Dejmkova, V. Ostatna, M. Fojta, K. Schwarzova-Peckova, Anal. Chim. Acta 2019, 1077, 30-66.

16. F. Karahan, Z. Başı, E. Keskin, P. Talay Pınar, Y. Yardım, and Z. Şentürk, ChemistrySelect 2020, 5, 12862-12868. DOI:10.1002/slct.202002921

17. B. C. Lourencao, R. F. Brocenschi, R. A. Medeiros, O. Fatibello-Filho, and R.C. Rocha-Filho, ChemElectroChem, 2020, 7, 1291-1311. DOI:10.1002/celc.202000050

18. S. O. Ganiyu, M. G. El-Din, Appl. Catal. B-Environ. 2020, 279, 119366. DOI:10.1016/j.apcatb.2020.119366

19. O. Sarakhman, L. Dubenska, L. Švorc, J. Electroanal. Chem. 2020, 858, 113759-113759.

DOI:10.1016/j.jelechem.2019.113759

20. P. Talay Pınar, S. Allahverdiyeva, Y. Yardım, and Z. Şentürk, Microchem. J. 2020, 104772-104772.

21. A. Yigit, Y. Yardım, and Z. Şentürk, J. Anal. Chem. 2020, 75, 653-661. DOI:10.1134/S1061934820050184

22. M. Yence, A. Cetinkaya, G. Ozcelikay, S. I. Kaya, and Sibel A. Ozkan, Crit. Rev. Anal. Chem.

DOI:10.1080/10408347.2020.1863769

23. H. S. Ali, A. A. Abdullah, P. T. Pınar, Y. Yardım, and Z. Şentürk, Talanta, 2017, 170, 384-391.

DOI:10.1016/j.talanta.2017.04.037

\section{Povzetek}

$\mathrm{Z}$ borom dopirano diamantno elektrodo smo anodno obdelali in jo uporabili za preprosto, hitro in cenovno ugodno določanje naravnega barvila lavsona. Z uporabo ciklične voltametrije smo za lavson v raztopini fosfatnega pufra (PBS, 0,1 $\mathrm{M}, \mathrm{pH}$ 2,5) dobili dobro opredeljen, ireverzibilen in difuzijsko nadzorovan oksidacijski vrh pri približno $+0,19 \mathrm{~V}$. Z dodatkom kationske površinsko aktivne snovi - cetiltrimetilamonijevega bromida (CTAB) smo dosegli značilno povečanje višin oksidacijskih vrhov. $Z$ uporabo voltametrije s kvadratnim spreminjanjem potenciala (»square wave voltammetry«) je bila pri optimiziranih eksperimentalnih pogojih umeritvena krivulja za lavson linearna v koncentracijskem območju $0,1-5,0 \mu \mathrm{M}$, meja zaznave pa je bila $0,029 \mu \mathrm{M}$ (v 0,1 M PBS ( $\mathrm{pH} 2,5) \mathrm{z}$ dodatkom $0,1 \mathrm{mM}$ CTAB). Uporabnost elektrode smo preverili z določanjem vsebnosti lavsona v komercialni kani, naravnem barvilu iz kaninih listov.

Except when otherwise noted, articles in this journal are published under the terms and conditions of the Creative Commons Attribution 4.0 International License 